\title{
Efek Pretreatment Ultrasonikasi Terhadap Hidrolisis Enzimatis Spirulina platensis Residue
}

\section{The effects of Ultrasonication Pretreatment to Enzymatic Hydrolysis of Spirulina platensis Residue}

\author{
Indriana Lestari ${ }^{\mathrm{a}^{*}}$, Heni Anggorowati ${ }^{\mathrm{a}}$ and Faizah Hadi ${ }^{\mathrm{a}}$ \\ a Program Studi Teknik Kimia, Fakultas Teknologi Industri, Universitas Pembangunan Nasional ”Veteran” Yogyakarta \\ Jl. SWK No. 104 (Ringroad Utara), Condong Catur, Yogyakarta 55283, Indonesia
}

\author{
Artikel histori : \\ Diterima 3 Januari 2021 \\ Diterima dalam revisi 29 April 2021 \\ Diterima 5 Mei 2021 \\ Online 6 Mei 2021
}

\begin{abstract}
ABSTRAK: Pengembangan energi terbarukan dari sumber mikroalga masih terus dikaji untuk mengatasi krisis energi dunia, salah satunya adalah biodiesel dari Spirulina platensis. Namun, proses pengepresan minyak dari Spirulina platensis menyisakan limbah yang disebut Spirulina platensis residue (SPR). SPR masih mengandung banyak karbohidrat dalam bentuk selulosa di dinding sel dan pati di dalam plastid. Karbohidrat dapat dimanfaatkan menjadi bioetanol melalui proses hidrolisis. Untuk mengoptimalkan hirolisis enzimatis terhadap karbohidrat maka diperlukan pretreatment dengan tujuan memecah dinding sel. Salah satu metode pretreatment adalah ultrasonikasi. Penelitian ini bertujuan untuk mengetahui pengaruh pretreatment ultrasonikasi terhadap hidrolisis enzimatis. Ultrasonikasi dilakukan dengan variasi waktu $\left(15,30\right.$, dan 45 menit) kemudian dilanjutkan hidrolisis pada suhu $40{ }^{\circ} \mathrm{C}$ selama 8 jam menggunakan enzim $\alpha$-amilase dan glukosidase (1:1). Hasil hidrolisis berupa gula reduksi dianalisis menggunakan metode Nelson Somogyi dan diperoleh waktu pretreatment optimal selama 30 menit dengan konsentrasi gula reduksi sebesar 2.493,3 mg/L.
\end{abstract}

Kata Kunci: mikroalga; Spirulina platensis residue; ultrasonikasi; hidrolisis enzimatik; gula reduksi

\begin{abstract}
The development of renewable energy from microalgae sources is still being studied to overcome the world energy crisis, one of which is biodiesel from Spirulina platensis. However, the extraction process from Spirulina platensis to obtain oil leaving waste called Spirulina platensis residue (SPR). SPR still contains carbohydrates in the form of cellulose in cell walls and starch in plastids. Carbohydrates can be converted into bioethanol through the hydrolysis process. To optimize the enzymatic hydrolysis of carbohydrates, pretreatment is needed to break down the cell walls. One method of pretreatment is ultrasonication. This study aimed to determine the effect of ultrasonication pretreatment on enzymatic hydrolysis. Ultrasonication was carried out with time variations $(15,30$, and 45 minutes) then continued hydrolysis at $40{ }^{\circ} \mathrm{C}$ for 8 hours using $\alpha$-amylase and glucosidase ( 1 : 1 ) enzymes. The results of hydrolysis in the form of reducing sugars were analyzed using the Nelson Somogyi method and obtained an optimal pretreatment time is 30 minutes with a reducing sugar concentration of $2.493,3 \mathrm{mg} / \mathrm{L}$.
\end{abstract}

Keywords: microalgae; Spirulina platensis residue; ultrasonication; enzymatic hydrolysis; reducing sugars

\section{Pendahuluan}

Produksi energi fosil Indonesia terutama minyak bumi telah mengalami penurunan selama 10 tahun terakhir. Pada tahun 2008 produksi minyak bumi mencapai 346 juta barel, sedangkan pada tahun 2018 hanya sekitar 283 juta barel. Penurunan ini disebabkan oleh usia sumur-sumur produksi utama yang umumnya sudah tua, sementara produksi sumur baru relatif masih terbatas. Di lain sisi penggunaan energi fosil memberikan efek negatif terhadap lingkungan terutama terhadap peningkatan emisi $\mathrm{CO}_{2}$ yang berdampak pada pemanasan global. Kedua permasalahan tersebut mendorong pemerintah untuk meningkatkan peran energi terbarukan secara terus-menerus sebagai upaya untuk menjaga ketahahanan dan kemandirian energi (Sekjen DEN, 2019).

Biomassa menjadi salah satu sumber alternatif energi terbarukan yang layak dikembangkan, karena biomassa adalah sumber energi yang sepenuhnya terbarukan. Seperti energi fosil, biomassa juga melepaskan $\mathrm{CO}_{2}$ sebagai hasil dari proses pembakaran, akan tetapi pemanfaatan biomassa

*Corresponding Author: +62 81328361351

Email: indriana.lestari@upnyk.ac.id 
tidak mengarah pada peningkatan $\mathrm{CO}_{2}$ di atmosfer karena berasal dari biogenik (Tkemaladze dan Makhashvili, 2016). Namun adanya perluasan penggunaan energi biomassa menimbulkan kekhawatiran terjadinya persaingan kebutuhan lahan, kebutuhan produk makanan dan kebutuhan komersial. Upaya untuk mengatasi hal ini adalah menggantikan biomassa pangan dengan biomassa nonpangan seperti mikroalga. Al Abdallah dkk. (2016) menyatakan bahwa mikroalga memiliki keunggulan dibandingkan dengan biomassa lainnya yaitu merupakan bahan non-pangan, tidak membutuhkan lahan karena tumbuh pada habitat perairan, dan dapat menghasilkan dua jenis biofuel (biodiesel dan bioetanol) karena mengandung minyak dan karbohidrat.

Mikroalga mengandung berbagai jenis karbohidrat seperti pati, selulosa dan hemiselulosa, tergantung jenis spesies mikroalga tersebut. Spirulina platensis adalah jenis mikroalga yang banyak dibudidayakan di Indonesia, memiliki kandungan karbohidrat sekitar 17-25\% (Christwardana dkk., 2018). Proses ektraksi minyak dari Spirulina platensis menyisakan padatan residu yang disebut dengan Spirulina platensis residue (SPR). Jamilatun dkk. (2019) melaporkan bahwa di dalam SPR masih terdapat karbohidrat sebesar 25,59\%. Karbohidrat mikroalga terletak pada dinding sel dan sitoplasma, sekitar 4-7\% dalam bentuk selulosa dan 51-60\% dalam bentuk gula netral non selulosa (VanderGheynst (2008) dalam Rinanti dan Purwadi, 2018). Oleh karena itu, diperlukan pretreatment untuk menghancurkan dinding sel dan mengeluarkan karbohidrat agar mudah untuk dikonversi menjadi bioetanol.

Proses pretreatment merupakan suatu tahapan yang memegang peranan penting dalam memproduksi bioetanol. Tahapan ini bertujuan untuk memperoleh karbohidrat dan gula reduksi (Harun, 2011). Metode-metode pretreatment berupa perusakan sel dan sakarifikasi mikroalga diantaranya secara kimia (asam kuat dan basa), fisik (homogenasi, ultrasonikasi, thermal, bed mill) dan enzimatis (selulase, amilase dan amiglukosidase). Untuk merubah karbohidrat menjadi gula reduksi (glukosa, fruktosa dan lain-lain) diperlukan proses hidrolisis (Talebnia dkk., 2010). Metode hidrolisis yang umum digunakan adalah acid treatment. Meskipun metode ini menghasilkan yield yang tinggi dan biaya operasi yang relatif murah, akan tetapi sifatnya yang berbahaya bagi lingkungan, memerlukan suhu operasi yang tinggi, dan membutuhkan alat yang tahan asam, menyebabkan banyak peneliti beralih pada hidrolisis enzimatis. Keunggulan hidrolisis enzimatis adalah ramah lingkungan, selektifitasnya tinggi, dan dioperasikan pada suhu rendah sampai menengah sehingga mudah diaplikasikan pada industri. Kelemahan enzim yaitu harganya yang mahal dan membutuhkan waktu operasi yang lebih lama (Gunerken dkk., 2015).

Penelitian yang menggunakan kombinasi dua buah metode pretreatment berbeda untuk memperoleh karbohidrat atau dan gula reduksi masih jarang dilakukan. Silva dkk. (2018) melaporkan bahwa kombinasi pretreatment enzimatis dan ultrasonikasi terhadap dinding sel Scenedesmus obliquus diperoleh hasil yield hidrolisis tertinggi sebesar 91\%. Enzim yang digunakan terdiri dari tiga buah enzim yaitu selulase, amiloglukosidase dan pektinase, sedangkan ultrasonikasi dilakukan selama 25 menit dengan amplitudo sebesar 50\%. Velazquez-Lucio dkk. (2018) memaparkan bahwa, beberapa teknologi baru seperti ultrasonikasi dapat digunakan dalam teknik kombinasi pretreatment mikroalga untuk meningkatkan penguraian dinding sel, sehingga menghasilkan pretreatment yang lebih efisien dengan biaya energi yang lebih rendah dan ektraksi senyawa target yang lebih tinggi.

Dari uraian tersebut maka perlu dilakukan penelitian untuk meningkatkan nilai guna SPR dengan cara memanfaatkan kandungan karbohidrat dalam SPR menjadi sumber bahan baku bioetanol atau senyawa lainnya. Optimalisasi perolehan karbohidrat dan gula reduksi dalam SPR ditingkatkan dengan cara mengkombinasikan dua metode pretreatment yaitu ultrasonikasi dan hidrolisis enzimatis. Oleh karena itu, tujuan dari penelitian ini adalah untuk mempelajari pengaruh pretreatment ultrasonikasi terhadap gula reduksi yang dihasilkan dari proses hidrolisis enzimatis.

\section{Metode Penelitian}

\subsection{Bahan}

Bahan-bahan yang digunakan pada penelitian ini terdiri dari Spirulina platensis residue (SPR) kering yang diperoleh dari residu padat hasil ekstraksi Spirulina platensis (SP), sedangkan S. platensis diperoleh dari Nogotirto Algae Park Yogyakarta Indonesia, enzim alfa-amylase dan amiloglukosidase diperoleh dari novozymes, reagensia Nelson A dan B, reagensia arsenomolybdat, dan larutan buffer asetat $\mathrm{pH} 4,8$.

\subsection{Alat}

Peralatan yang digunakan pada penelitian ini adalah sonicator batch untuk pretreatment, reaktor hidrolisis sederhana yang terdiri dari hot plate magnetic stirrer, labu leher dua, dan termometer, serta centrifuge yang digunakan untuk memisahkan sampel padat dan cair dari proses hidrolisis.

\subsection{Cara Kerja}

Langkah kerja pada penelitian ini terbagi menjadi tiga tahapan yaitu pretreatment ultrasonikasi sampel SPR menggunakan ultrasonicator batch, dilanjutkan hidrolisis enzimatik dan diakhiri dengan analisis sampel cair dan padat. Pada pretreatment ultrasonikasi, sebanyak 2 gram SPR yang telah dihaluskan dan disaring dengan ayakan kawat dimasukkan ke dalam gelas beker dan ditambahkan $200 \mathrm{~mL}$ larutan buffer asetat. Setelah tercampur homogen, campuran diultrasonikasi menggunakan ultrasonicator batch dengan suhu operasi $40^{\circ} \mathrm{C}$ dan frekuensi $40 \mathrm{KHz}$ selama waktu tertentu (15, 30 dan 45 menit). Campuran hasil utrasonikasi selanjutnya dihidrolisis selama 8 jam dengan menggunakan kombinasi dua buah enzim berkonsentrasi $1 \%$ $(1: 1, \mathrm{v} / \mathrm{v})$ di dalam reaktor. Selama hidrolisis, suhu dijaga konstan pada $40^{\circ} \mathrm{C}$ dan kecepatan pengadukan $750 \mathrm{rpm}$. Pada selang waktu tertentu, sampel diambil kemudian direndam dalam air panas bersuhu $90^{\circ} \mathrm{C}$ selama 10 menit 
untuk menghentikan aktivitas enzim. Setelah dingin campuran dipisahkan menggunakan centrifuge.

\subsection{Analisa}

Supernatan yang diperoleh dari hasil pemisahan selanjutnya dianalisis total gula reduksinya menggunakan Metode Nelson Somoygi, sedangkan presipitat yang telah dikeringkan dianalisis morfologinya dengan menggunakan scanning electron microscope (SEM).

\section{Hasil dan Pembahasan}

Target utama dalam penelitian ini adalah untuk mendapatkan waktu pretreatment ultrasonikasi yang optimal dan membandingkan bagaimana waktu ultrasonikasi berpengaruh terhadap konsentrasi gula reduksi yang dihasilkan pada proses hidrolisis enzimatis. Enzim yang digunakan untuk menghidrolisi polisakarida pada dinding sel dan pati adalah $\alpha$-amilase dan amiloglukosidase, hal ini dikarenakan karbohidrat dari mikroalga ditemukan pada dinding sel dalam bentuk selulosa dan dalam plastida dalam bentuk pati sebagai cadangan gula utama (Chen dkk., 2013). Frekuensi ultrasonikasi didasarkan pada referensi Wang dkk. (2014) yang menyatakan bahwa untuk biomassa heterogen dan katalisis enzimatis lebih sesuai menggunakan sonikasi berfrekuensi rendah dalam kisaran $20-50 \mathrm{KHz}$. Suhu dan $\mathrm{pH}$ hidrolisis dijaga konstan masing-masing $40^{\circ} \mathrm{C}$ dan 4,8 agar sesuai dengan aktivitas enzim.

\subsection{Pretreatment Ultrasonikasi}

Pada percobaan pendahuluan memberikan hasil bahwa pretreatment ultrasonikasi terhadap SPR mampu mengurai dinding sel $S$. platensis, mengeluarkan karbohidrat dan menghasilkan gula reduksi. Hal tersebut dibuktikan pada Gambar 1 yang menunjukkan konsentrasi gula reduksi SPR tanpa pretreatment sebesar $36,5 \mathrm{mg} / \mathrm{L}$, sangat kecil bila dibandingkan dengan konsentrasi SPR dengan pretreatment yang mengalami kenaikan konsentrasi cukup signifikan seiring bertambahnya waktu ultrasonikasi.

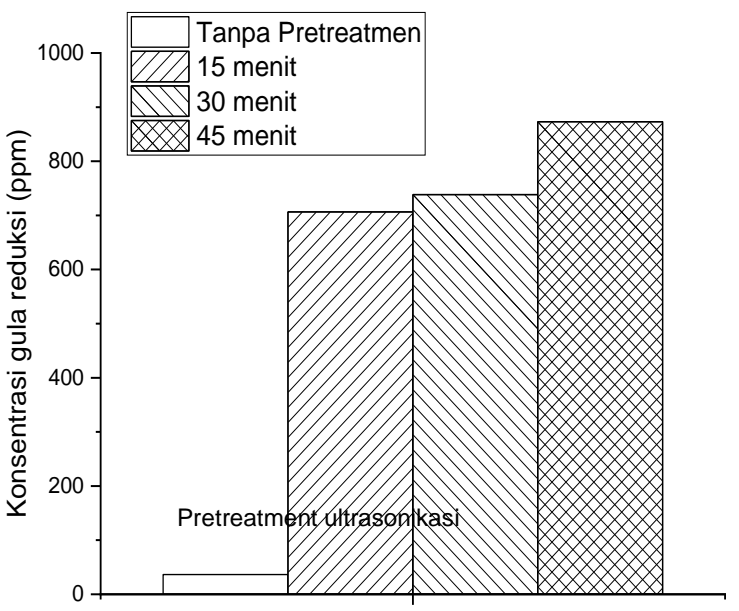

Gambar 1. Konsentrasi gula reduksi pada berbagai pretreatment ultrasonikasi

Jeon dkk. (2013) dan Somaglino dkk. (2011) melaporkan bahwa ultrasonikasi mengakibatkan luruhnya dinding sel

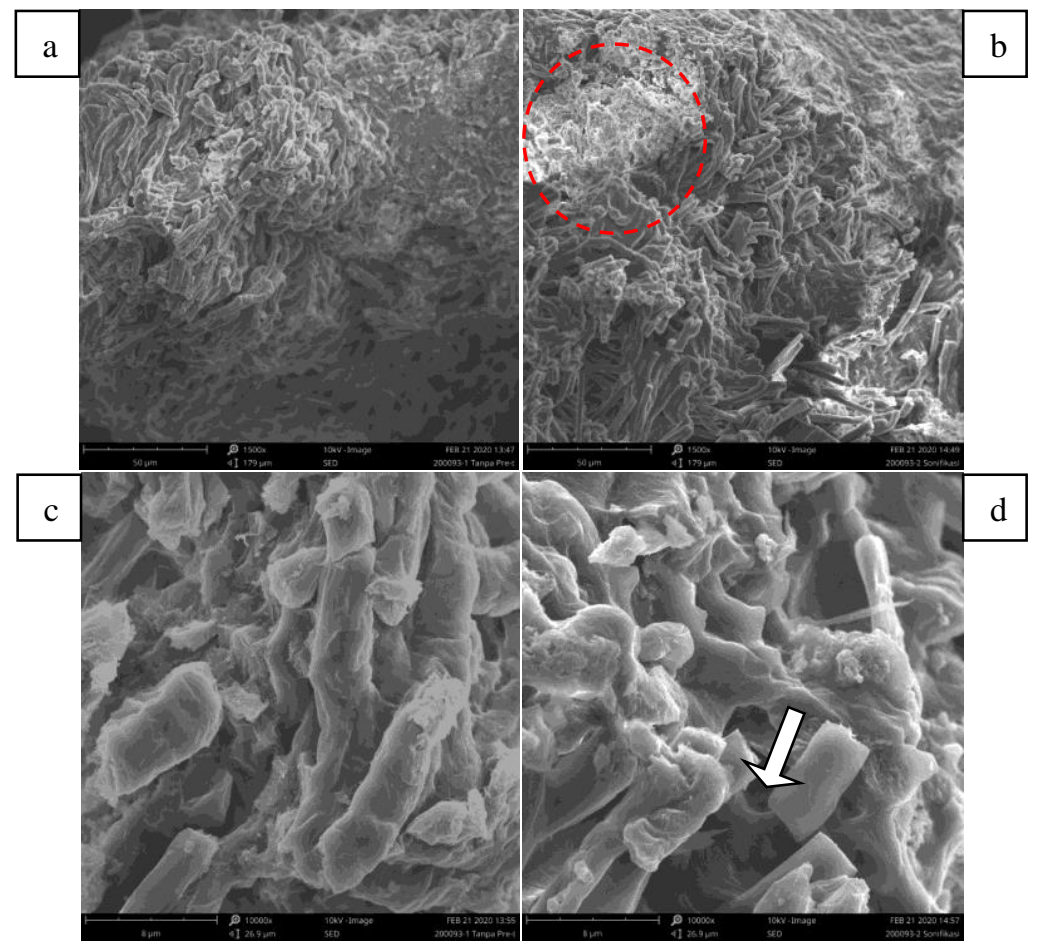

Gambar 2. Citra SEM pada SPR (a) dan (c) SPR non-pretreatment; (b) dan (d) SPR pretreatment ultrasonikasi 30 menit 
dan melepaskan substrat intraseluler seperti karbohidrat, protein, pigmen ke dalam media pelarut. Ultrasonikasi mampu menghasilkan lebih banyak karbohidrat gugus hidroksil dari bagian dalam maupun luar permukaan sel sebagai akibat dari disintegrasi sel dan lisis, serta semakin lama waktu ultrasonikasi menghasilkan peningkatan jumlah karbohidrat terlarut.

Hasil citra SEM SPR (Gambar 2) menunjukkan bahwa pretreatment ultrasonikasi selain dapat mengurai dinding sel juga dapat mendispersikan S. platensis secara merata dalam pelarut. Gambar 2 memperlihatkan bahwa terjadi perubahan morfologi SPR, dimana struktur SPR nonpretreatment (Gambar 2(a) dan (c)) masih tampak utuh meskipun ada sedikit kerusakan sel yang diduga akibat dari proses ekstrasi minyak. Namun berbeda dengan ultrasonikasi (Gambar 2(b)) beberapa SPR mengalami kerusakan dan mengalami perubahan bentuk (Gambar 2(d)). Hasil citra SEM juga menunjukkan adanya aglomerasi $S$. platensis pada kondisi non-pretreatment dan setelah ultrasonikasi (Gambar 2b) tingkat aglomerasi berkurang, hal ini nampak pada munculnya ruang-ruang kosong diantara sel. Silva dkk. (2018) menyatakan bahwa penguraian dinding sel dengan menggunakan pretreatment ultrasonikasi memberikan efisiensi hidrolisis enzimatis yang lebih tinggi dibandingkan dengan autoclave, hal ini dikarenakan pada pretreatment ultrasonikasi tidak terjadi hambatan difusi seperti yang terjadi pada autoclave, dimana sel-sel Scenedesmus obliquus membentuk agregat.

\subsection{Hidrolisis Enzimatis}

Perbedaan waktu pretreatment ultrasonikasi SPR dilanjutkan hidrolisis enzimatis SPR pada kondisi yang sama menghasilkan konsentrasi gula reduksi yang berbeda. Semakin lama waktu ultrasonikasi, semakin besar konsentrasi gula reduksi yang diperoleh. Kombinasi pretreatment ultrasonikasi dan hidrolisis enzimatis juga memberikan hasil yang signifikan.

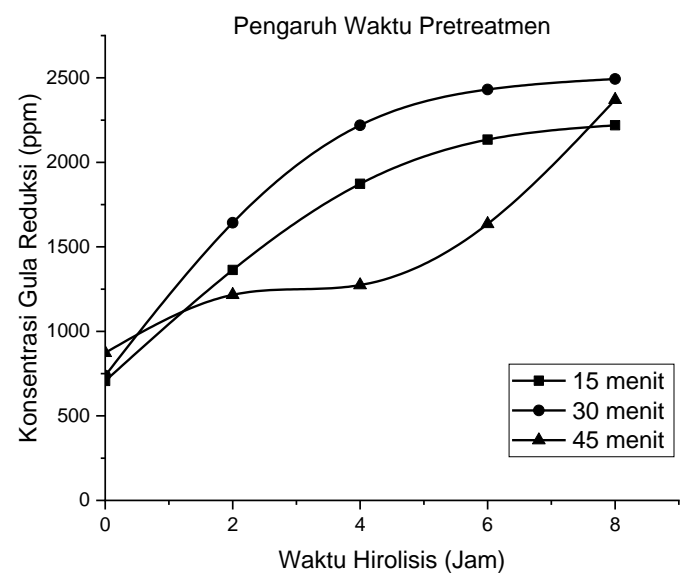

Gambar 3. Pengaruh waktu pretreatment terhadap konsentrasi gula reduksi pada hidrolisis enzimatis SPR

Gambar 3 menunjukkan bahwa dalam waktu 2 jam gula reduksi yang diperoleh dari proses hidrolisis meningkat dengan tajam dan terus meningkat. Hal ini menunjukkan bahwa pretreatment ultrasonikasi memberikan kemudahan kepada enzim untuk dapat mengakses karbohidrat, sehingga proses hidrolisis berjalan cepat. Mekanisme hidrolisis enzimatis dimulai saat enzim dapat mencapai karbohidrat, enzim $\alpha$-amilase memecah pati menjadi dekstrin dan oligosakarida dengan cara memecah ikatan $\alpha-(1,4)$ baik yang terdapat dalam amilosa maupun amilopektin dan selanjutnya ikatan $\alpha-(1,4)$ dan $\alpha-(1,6)$ dihidrolisis lanjut oleh enzim amiloglukosidase, sehingga terjadi transformasi dari oligosakarida menjadi molekul dengan berat molekul yang lebih kecil yaitu monomer- monomer glukosa (Shokrkar dkk., 2017).

Hasil tersebut sesuai dengan penelitian yang dilakukan Zheng dkk. (2013) dan Kuakpetoon dan Wang (2007) bahwa ultrasonikasi dapat merubah struktur granula pati yang berbentuk kristal dengan gelatinisasi, distorsi daerah semi kristal dan peningkatan penyerapan air granula pati, sehingga meningkatkan aksestabilitas enzim yang menyebabkan proses hidrolisis karbohidrat berjalan lebih efisien. Setelah 8 jam hidrolisis, konsentrasi gula reduksi tertinggi dicapai dengan pretreatment ultrasonikasi 30 menit sebesar 2.493,3 mg/L, sedangkan konsentrasi gula reduksi terendah sebesar 2.219,2 mg/L dihasilkan pada pretreatment ultrasonikasi 15 menit. Hal ini diduga dengan waktu ultrasonikasi yang singkat belum cukup memberikan energi untuk mengurai dinding sel dan mengurai aglomerasi pada SPR sehingga menghalangi enzim untuk dapat mengakses karbohidrat. Di lain sisi dengan semakin lama waktu ultrasonikasi, gula reduksi yang diperoleh justru mengalami penurunan. Penurunan ini diduga bahwa semakin lama waktu ultrasonikasi akan memberikan energi berlebih kepada sistem sehingga mengakibatkan terjadi degradasi karbohidrat menjadi senyawa-senyawa lainnya seperti senyawa asam dan furfural, yang menyebabkan turunnya konsentrasi gula reduksi. Oleh karena itu pemilihan kondisi pretreatment sangatlah penting untuk dilakukan, karena kondisi yang tidak sesuai akan menyebabkan terjadinya degradasi senyawa tertentu seperti karbohidrat dan protein.

\section{Kesimpulan}

SPR memiliki potensi untuk diproduksi menjadi bioetanol dan senyawa lainnya. Pretreatment ultrasonikasi mampu meningkatkan perolehan gula reduksi, dengan cara memberi aksesibitas kepada enzim, sehingga reaksi hidrolisis berjalan efisien. Pemilihan kondisi yang tepat penting untuk dilakukan agar diperoleh substrat yang diinginkan dan mencegah terjadinya pemborosan energi. Kondisi optimal pretreatment ultrasonikasi SPR diperoleh selama 30 menit dengan konsentrasi gula reduksi sebesar 2.493,3 mg/L. Integrasi produksi biofuel dan pengolahan SPR layak dikembangkan, sebagai upaya untuk mengurangi dampak lingkungan, menyiapkan energi bersih dan menaikkan profitabilitas produksi biofuel berbahan baku Spirulina platensis.

\section{Ucapan Terima kasih}


Penulis mengucapkan terima kasih kepada LP3M Universitas Pembangunan Nasional Veteran Yogyakarta yang telah membiayai penelitian ini melalui Hibah Penelitian Dasar, Terapan, Kelembagaan, dan Kluster Universitas Pembangunan Nasional "Veteran" Yogyakarta No. 519/UN62/KPN2OL9 tanggal 21 Oktober 2019.

\section{Daftar Pustaka}

Al Abdallah, Q., Nixon, B.T., Fortwendel, J.R., 2016, The enzymatic conversion of major algal and cyanobacterial carbohydrates to bioethanol, Frontiers in Energy Research, Vol.4, Article 36, November: 1-15.

Chen, C.Y., Zhao, X.Q., Yen, H.W., Ho, S.H., Cheng, C.L., Lee, D.J., Bai, F.W., Chang, J.S., 2013, Microalgaebased carbohydrates for biofuel production, Biochem. Eng. J. Vol.78, September: 1-10.

Christwardana, M., Nur, M.A., Hadiyanto, 2013, Spirulina platensis: potensinya sebagai bahan pangan fungsional. Jurnal Aplikasi Teknologi Pangan. Vol.2, No.1, Februari: 1-4.

Gunerken, E., D’Hondt, E., Eppink, M.H.M., GarciaGonzales, L., Elst, K., Wijffels, R.H., 2015, Cell disruption for microalgae biorefeneries, Biotechnology Advances. Vol. 33 Issue 2, April: 243-260.

Harun, R. M., Danquah, M.K., 2011, Enzymatic hydrolysis of microalgal biomass for bioethanol production, Chemical Engineering Journal. Vol.168 Issue 3, April: 1079-1084.

Jamilatun, S., Budhijanto, Rochmadi, Yuliestyan, A., Budiman, A., 2019, Effect of grain size, temperature and catalyst amount on pyrolysis production of Spirulina palntesis redidue (SPR), International Journal of Technology. Vol. 10 No. 3, Mei: 541-550.

Jeon, B.H., Choi, J.A., Kimm, H.C., Hwangm, J.H., AbouShanab, R.A.I., Dempsey, B.A., Regan, J.M., Kim, J.R., 2013, Ultrasonic disintegration of microalgal biomass and consequent improvement of bioaccessibility/bioavailability in microbial fermentation. Biotechnol for Biofuels, Vol. 6 No.1, Maret: 37.

Kuakpetoon, D., Wang, Y.J., 2007, Internal structure and physicochemical properties of corn starches as revealed by chemical surface gelatinization, Carbohydr. Res., Vol. 342 No. 15, Juni; 2253-2263.

Rinanti, A., Purwadi, R., 2018, Pemanfaatan mikroalga blooming dalam produksi bioetanol tanpa proses hidrolisis. Prosiding Seminar Nasional Kota Berkelanjutan 2018, hlm. 281-292.

Sekjen DEN. 2019. Outlook Energi Indonesia 2019. hlm. 17. Jakarta: Dewan Energi Nasional.

Shokrkar, H., Ebrahimi, S., Zamani, M., 2017, Bioethanol production from acidic and enzymatic hydrolysates of mixed microalgae cul ture, Fuel, Vol. 200, Juli: 380386.

Silva, C.E.F., Meneghello, D., Abud, A.K.S., Bertucco, A., 2018, Pretreatment of microbial biomass to improve the enzymatiz hydrolysis of carbohydrates by ultrasonication: yield vs energy consumption. Journal of King Saud University, Vol. 32 Issue 1, Januari: 1-8.

Somaglino, L., Bouchoux. G., Mestas, J., Lafon, C., 2011, Validation of an acoustic cavitation dose with hydroxyl radical production generated by inertial cavitation in pulsed mode: application to in vitro drug release from liposomes. Ultrason Sonochem. Vol. 18 Issue 3, Mei: 577-588.

Talebnia, F., Karakashev, D., Angelidaki, I., 2010, Production of bioethanol from wheat straw: An overview on pretreatment, hydrolysis and fermentation. Bioresour Technol, Vol.101 Issue 13, Juli: 4744-4753.

Tkemaladze, G.S., Makhashvili, K.A., 2016, Climate changes and photosynthesis. Annals of Agrarian Science, Vol.14 Issue 2, Juni: 119-126.

Velazquez-Lucio, J., Rodríguez-Jasso, R.M., Galindo, A.S., Cisneros, D.E.C., Aguilar, C.N., Fernandes, B.D., Ruiz, H.A., 2018, Microalga biomass pretreatment for bioethanol production: a review. Biofuel Research Journal, Vol. 17 Issue 1 No.1, p: 780-791.

Wang, M., Yuan, W., Jiang, X., Jing, Y., Wang, Z., 2014, Disruption of microalgal cells using high-frequency focused ultrasound. Bioresour Technol, Vol. 153, Februari: 315-321

Zheng, J., Li, Q., Hu, A., Yang, L., Lu, J., Zhang, X., Lin, Q., 2013, Dual-frequency ultrasound effect on structure and properties of sweet potato starch. Starch J., Vol. 65, Februari: 621-627. 